\title{
A kockázatalapú bankszabályozás előretörése és visszaszorulása - az ösztönzési struktúrák szerepe
}

A globális pénzügyi válságot követően a bankszabályozás szemlélete jelentősen átalakult. Ennek egyik fontos tényezője, hogy a korábbi, kockázatalapú bankszabályozással szemben megerősödtek a szabályozás nem kockázatérzékeny elemei. A kockázatalapú szabályozás, vagyis a bankok belső kockázatkezelési modelljeinek szabályozási célú elfogadása a válság előtti bankszabályozás (Bázel-II.) legfontosabb fejleménye volt. Ezzel a szabályozóhatóságok elismerték, hogy a bankok jobban, pontosabban képesek saját kockázataikat mérni, mint a szabályozó- és felügyeleti hatóságok. A válság idején azonban nyilvánvalóvá vált, hogy a kockázatalapú szabályozás, elsősorban a rossz ösztönzési struktúrák miatt, jelentősen alulbecsüli a kockázatokat. Ez okozta a válság utáni visszarendeződést: a Bázel-III. szabályozás oly módon csökkenti jelentősen a szabályozás kockázatérzékenységét, hogy számos nem kockázatalapú elemet is beépít eszköztárába. Ez a visszarendeződés erősen vitatott, hiszen első ránézésre nem más, mint visszalépés a régi, elavult szabályozási rendszer felé. A tanulmány a kockázatalapú szabályozás válság előtti előretörését és válság utáni visszaszorulását vizsgálva arra a következtetésre jut, hogy a kevert rendszerek jobbak, mint akár a pusztán kockázatalapú, akár az egyáltalán nem kockázatérzékeny rendszer.*

Journal of Economic Literature (JEL) kód: G01, G21,G28.

A 2008-tól kibontakozó globális pénzügyi válság (Global Financial Crisis, GFC) több szempontból is alapvetően megváltoztatta a bankszabályozás szemléletét. E változások közül a legmarkánsabb a makroprudenciális szabályozás térnyerése. Emellett abban is komoly változás történt, hogy a szabályozás milyen mértékben támaszkodik a legjobb banki gyakorlatokat jelentő, a bankok saját belső kockázatkezelési modelljeiből származó eredményeknek a tőkekövetelmény-számításhoz történő elfogadására

* A cikk egy korábbi változata előadásra került az ECPR SG on Regulatory Governance 2018. évi konferenciáján (Lausanne, július 4-6.). A szerző köszönetet mond a konferencia résztvevőinek, továbbá Király Júliának, Neményi Juditnak és Szöke Magdolnának a korábbi változathoz füzött hasznos észrevételeikért.

Mérő Katalin a Budapesti Gazdasági Egyetem docense (e-mail: mero.katalin@uni-bge.hu).

A kézirat első változata 2018. augusztus 3-án érkezett szerkesztőségünkbe.

DOI: http://dx.doi.org/10.18414/KSZ.2018.10.981 
és azoknak a szabályozásba való integrálására. Cikkünkben ez utóbbi kérdéskörrel foglalkozunk: a bankszabályozás egyre erősebben kockázatalapúvá válásával a globális pénzügyi válság előtt, majd ennek a folyamatnak a megtörésével és visszafordulásával a válságot követően.

A válság elötti évtizedben a bankszabályozói gyakorlatot az jellemezte, hogy egyre erősebben támaszkodott a bankok által kifejlesztett és eredetileg csak belső kockázatkezelési célokra használt modellekre. Ezzel a szabályozás azt ismerte el, hogy a bankok sokkal jobban ismerik és ezáltal pontosabban képesek mérni az általuk vállalt kockázatokat, mint a szabályozóhatóságok.

Első lépésként a bankok kereskedési könyvi pozícióinak modellezésére általánosan használt kockáztatottérték-modelleket (Value-at-Risk models) emelte be a szabályozás a tőkemegfelelési előírások eszköztárába ( $B C B S$ [1996]). A folyamat csúcspontját jelentette a Bázel-II. tőkeszabályok 2004-es elfogadása (BCBS [2004]) és alkalmazásának bevezetése közvetlenül a válság előtt. ${ }^{1}$ A Bázel-II. szabályozás a magas kockázattudatossággal és kiemelkedő kockázatkezelési gyakorlattal rendelkező bankok számára megengedte, hogy belső modelljeiket felhasználják a szabályozási hitelkockázati tőkekövetelmény meghatározásához. Ez az intézmények számára nem azt jelentette, hogy teljes egészében saját modelljük alapján történt volna a tökekövetelmény-számítás, hanem azt, hogy a szabályozók fejlesztették ki azt a hitelkockázati modellt, amelynek bizonyos paramétereit a bankok becsülhették. Az új előírások leginkább megengedők a müködési kockázat Bázel-II. szabályozás által bevezetett tőkekövetelmény-számításánál voltak: a legfejlettebb kockázatkezelési rendszert alkalmazó bankok fejlett mérési módszereik (Advanced Measurement Approach, AMA) keretében szinte teljesen szabadon modellezhették a müködési kockázati tőkekövetelményt.

Így összességében a bankok mindhárom legfontosabb kockázati típusánál (hitel-, piaci és müködési), ahol tőkekövetelményt írt elő a szabályozás, ${ }^{2}$ azt meghatározhatták a saját banki modelljeik használatával is, ha a felügyeleti hatóság az úgynevezett modellvalidációs eljárás keretében jóváhagyta.

Első ránézésre a modellek használatának szabályozói elfogadása hatalmas előrelépésnek látszik, hiszen összhangban van azzal, hogy a tőke legfontosabb funkciója, hogy veszteségelnyelö pufferként viselkedjen a banki kockázatokkal szemben, és így a betétesek pénzének legfőbb védelmezője legyen (Diamond-Rajan [2000]). Ennek megfelelően a Bázel-II. szabályozás egyik deklarált alapelve volt, hogy azzal is elismerje a modellalapú szabályozás magasabbrendűségét, hogy a pontosabb kockázatmérést lehetővé tevő modellek fejlesztésének és alkalmazásának költségét kisebb fajlagos tőkekövetelménnyel honorálja, szemben a pontatlanabb és így nagyobb

${ }^{1}$ Az EU-ban 2007-től lehetőség, 2008-tól pedig kötelező volt a Bázel-II. szabályok implementálása. A Bázel-II. szabályrendszer európai megfelelőjét az EU tőkemegfelelési irányelve, a Capital Requirement Directive (CRD) jelentette.

${ }^{2}$ A Bázel-II. hárompilléres rendszerében az első pillér keretében a bankoknak a hitelkockázatok, a piaci kockázatok, valamint a működési kockázatok mögé kell tőkét allokálni. A második pillér keretében - a felügyelet felülvizsgálati eredményének függvényében - a felügyeletek ugyanezen kockázatokra kiegészítő jelleggel többlettőkét is előirhhatnak, illetve a bank más kockázatai mögé is határozhatnak meg tőkekövetelményt. 
felülbecslést igénylő standard módszerrel. A globális pénzügyi válság, illetve az ennek során bekövetkező bankválságok azonban megkérdőjelezték, hogy a bankok belső kockázatkezelési modelljeire támaszkodó tőkekövetelmény-számítás valóban akkora előrelépést jelent-e, amekkorának első ránézésre látszott. Bár a Bázel-II., vagyis a modellalapú tőkeszámítások 2007/2008-as bevezetése miatt a válság kitörésekor még csak minimális empirikus anyag állt rendelkezésre ennek hatásairól, az már 2008-ra is nyilvánvaló volt, hogy a modellalapú tőkeszámításokkal meghatározott tőkeszint egyrészt túl alacsony, másrészt olyan beépített ösztönzőket tartalmazott, amelyek a banki stabilitás ellen hatottak. A válságot követő Bázel-III. szabályozás keretében megszűnt a müködési kockázatok szabad modellezhetősége (vagyis kivezetésre került az AMA-módszer), alapvetően megváltozott a piaci kockázatok modellezésének elvi keretrendszere, és számos korlátozás épült be a szabályozásba a hitelkockázati modellekből számított tőkekövetelmény alkalmazásával kapcsolatban. Ez a cikk a modellek használatára, illetve korlátozására vonatkozó szabályozási lépések közül kizárólag a hitelkockázati modellek szabályozói megítélésének változásával foglalkozik. Ennek keretében mindkét szabályozói szemléletü fordulatot (vagyis a hitelkockázati modellek irányába való nyitást, majd ezek használatának korlátozását) elemezi, nemcsak a modellek hatékonysága, hanem a mögöttes ösztönzési struktúrák szempontjából is, vagyis azt a kérdést is felteszi, hogy a szabályozás vajon a magánérdeket vagy a közérdeket szolgálja (Barth és szerzőtársai [2005], [2013]).

A cikk felépítése a következő: először a kockázatalapú bankszabályozás fogalmát, valamint előretörésének folyamatát és motivációit tekintjük át. Majd azokat a kockázatokat elemezzük, amelyek a kockázatalapú szabályozás használatához kötődnek. Ezt követően azt mutatjuk meg, hogy miért van szükség a kockázatalapú bankszabályozás hatókörének korlátozására és kiegészítésére nem kockázatalapú szabályozói eszközökkel. Az utolsó rész tartalmazza a következtetéseket.

\section{A kockázatalapú szabályozás fogalma és térnyerése}

Kidolgozása és bevezetése időszakában - az 1980-as évek második felében, illetve az 1990-es évek elején - az első bázeli tőkeegyezményt is kockázatalapú szabályrendszernek tekintették. Egyrészt ez vezette be az eszközök kockázati súlyozását (risk weighted assets, RWA). Bár csak négy kockázatisúly-kategóriát használt (0, 20, 50 és 100 százalékos), ezek a súlyok az egyes eszközkategóriák különböző kockázatosságára reflektáltak. A szabályozás elismerte, hogy az országkockázat az egyes országok saját pénznemében és bizonyos országok esetében devizában is nullához közeli (0 kockázati súly); hogy a jellemzően likviditáskezelési célokra szolgáló bankközi hitelek kockázata jóval alacsonyabb, mint a vállalati hiteleké (20 százalékos kockázati súly); hogy a lakossági jelzáloghitel-portfólió erősen diverzifikált és fedezett (50 százalékos kockázati súly); s eközben 100 százalékos kockázati súlyt rendelt minden vállalati hitel mögé. Másrészt a Bázel-I. szabályozás újdonsága volt az is, hogy nemcsak az egyes eszközök, hanem a mérlegen kívüli tételek mögé is elöírt kockázattal súlyozott tőkekövetelményt, hiszen azok - ha mérlegtétellé válnak - ugyanolyan banki kockázatokat keletkeztetnek, mint 
a mérlegtételek. Ezt az úgynevezett hitel-egyenértékesítési kockázati súlyokkal (hitelegyenértékesítési tényezőkkel) oldották meg.

Lényegében tehát a Bázel-I. szabályozás által bevezetett nyolcszázalékos tőkekövetelmény egy olyan szabályozói kockázati becslés, amely a banki mérlegen belüli és mérlegen kívüli tételek hitelkockázatát fejezte ki, vagyis azt az összeget, amelylyel a tulajdonos befektetésének, nem pedig a bankbetéteknek kell szemben állnia a vállalt kockázatokkal. Ennek megfelelően a Bázel-I. szabályozás elfogadását követően, de még a tényleges bevezetése előtt számos tanulmány elemezte az új kockázatalapú tőkeszabályozás hatását (lásd például Avery-Berger [1991], Eyssell-Arshadi [1989], Cordell-King [1995], Kane [1995], Cooper és szerzőtársai [1991]). Ezek a tanulmányok jellemzően a bázeli tőkeegyezményt megelőző, a tőkeáttétel mértékének korlátozására épülő szabályozáson alapuló tőkekövetelményt hasonlították össze a Bázel-I. szerinti tőkekövetelménnyel, amelyet kockázatalapú tőkekövetelménynek neveztek. A későbbiekben, ahogy a kockázatok modellalapú mérése egyre integránsabb részévé vált a banki tőkeszabályozásnak, már nem nevezték kockázatalapúnak a Bázel-I. szerinti tőkekövetelményeket. A Bázel-II. szabályozás kialakításával és bevezetésével a kockázatalapú bankszabályozáson a banki kockázatkezelési modellek szabályozói elfogadásán és azoknak a szabályozási tőkekövetelmény meghatározására való felhasználásán alapuló rendszereket, vagyis a Bázel-II. tőkeszabályozás keretében kidolgozott, fejlettebb kockázatmérési módszereket értjük.

A Bázel-I. tőkeszabályozással szemben megfogalmazott legfontosabb kritika éppen az volt, hogy nem kellően kockázatérzékeny, és így nagyon könnyen arbitrálható. Azaz, ha ugyanazon a kockázati súlyozású eszközkategórián belül a bank növeli az egységnyi eszköz visszafizetésének kockázatosságát, akkor nem változik a tőkekövetelménye, miközben nagyobb kockázatot vállal magasabb profitkilátással. Például, ha egy bank a vállalati hitelezés során növeli a kockázati étvágyát, és nagyobb nemteljesítési (visszafizetési) kockázatú hiteleket nyújt magasabb kockázati felár mellett, akkor a tőkekövetelménye nem változik, a felügyeleti hatóság sem kifogásolhatja a tőkeszintjét, miközben a változatlan szintű tőke már kevésbé képes a potenciális veszteségek elnyelésére, és így a betétesek pénzének védelmére. Emellett, annak ellenére, hogy elvileg maga a nyolcszázalékos tőkekövetelmény is egy olyan mesterséges változó, amely a banki kitettségek értékének kockázatosságát fejezi ki, ezt semmilyen érdemleges empirikus elemzés nem támasztotta alá. A tőkekövetelmény nyolcszázalékos szintje politikai alku eredménye volt, ez volt az a szint, amit a tőkeerősebb amerikai és európai bankok viszonylag könnyen tudtak teljesíteni, miközben a gyengébb tőkeerejü japán bankoknak is még éppen elfogadható volt (Cook [1990], Tarullo [2008]). Vagyis az a hitelkockázati tőkekövetelmény, amelyet abban az időben kockázatalapúnak hívtak, egyáltalán nem volt közvetlen kapcsolatban a bank hitelezési kockázatának tényleges szintjével (JonesMingo [1998], Király [2002]). 1999-re mintegy 100 ország vezette be a Bázel-I. tőkeegyezményen alapuló bankszabályozást (BCBS [1999a]), azonban az elvi kritikák ellenére a Bázel-I. hatásait elemző tanulmányok nem találtak arra mutató bizonyítékot, hogy a bankok szabályozási arbitrázs céljából valóban megnövelték volna a kockázati étvágyukat (Sheldon [1996], BCBS [1999a]). 
Eközben az 1990-es évek második felében a nemzetközileg aktív nagybankok, annak érdekében, hogy a kockázataikat pontosabban tudják mérni, saját hitelkockázati modelleket fejlesztettek ki. Számos modell vált általánosan elfogadottá és széles körben használttá, mint például a J. P. Morgan által fejlesztett CreditMetrics vagy a Credit Suisse CreditRisk+ modellje (Gordy [2000]). Ezeknek a modelleknek a segítségével a bankok képessé váltak arra, hogy meghatározzák hitelezési kockázatuk úgynevezett „gazdasági” tőkeszintjét, vagyis azt a tőkenagyságot, amelyre saját számításaik szerint szükségük van ahhoz, hogy a hitelezési kockázataikat tőkével tudják fedezni. A modellek legfontosabb felhasználási területét a bankok belső, kockázatalapú tőkeallokációs rendszere jelentette, amelynek segítségével a bankok legfontosabb jövedelmezőségi mutatójukat, a kockázattal korrigált tőkemegtérülést (risk adjusted return on capital, RAROC) tudták számítani. Nyilvánvaló, hogy minél közelebb van egymáshoz a bankok szabályozás szerinti tőkekövetelménye és a gazdasági tőkeszükséglete, annál nagyobb a banki tőkebefektetések hozama, a sajáttőke-arányos jövedelem (ROE). Minél inkább meghaladja a bankokra vonatkozó szabályozási tőkekövetelmény nagysága a gazdasági tőkeszükséglet bank által számított szintjét, annál kedvezőtlenebb a banki szabályozásnak a ROE-re gyakorolt hatása, miközben a gazdasági tőke szintje feletti szabályozói tőkekövetelmény felesleges szabályozói költségnek látszik a bank szempontjából. Ennek megfelelően a bankok erős érdekévé vált, hogy nyomást helyezzenek a szabályozókra azért, hogy a szabályozás fogadja el a banki legjobb kockázatkezelési gyakorlaton alapuló modelleket, és engedje meg azok felhasználását a hitelkockázatok szabályozói tőkekövetelményeinek meghatározásához.

Az 1990-es évek második felének banki és egyéb pénzügyi intézményi válságai a szabályozóhatóságokat is a tőkeszabályozás megújítására ösztönözték. Ahogy arra JonesMingo [1998] (60. o.) rámutatott, bár a bankok által kifejlesztett belső modelleknek voltak problémái, a szabályozóhatóságoknak abban az időben nem volt más, hosszabb távon is működőképesnek látszó alternatív megoldási javaslatuk, mintsem lehetővé tenni a belső hitelkockázati modellek alkalmazását a hitelkockázati tőkekövetelmény számításához. A Bázel-II. szabályozási rendszer kidolgozására való felkészülés részeként a Bázeli Bizottság áttekintette és összegezte a bankok hitelkockázati modellezési gyakorlatát (BCBS [1999b]), hogy dönteni tudjon a modellek szabályozásban való használatáról. Az elemzés a hitelkockázati modellek használatának több előnyös vonását is kiemelte, mindenekelőtt azok kockázatérzékenységével, rugalmasságával és a kockázatkezelés fejlesztésére irányuló ösztönzési hatásával kapcsolatban.

Mindezen előnyös tulajdonságok ellenére a Bázeli Bizottság arra a következtetésre jutott, hogy a szabályozási célra való használat előtt még számos problémát meg kell oldani (BCBS [1999b] 4. o.). Néhány hónappal később, 1999 júniusában a Bázeli Bizottság közzétette a Bázel-II. szabályozási rendszerre vonatkozó első konzultációs dokumentumát (BCBS [1999c]), amely nagyon komoly lépést jelentett a kockázatalapú hitelkockázati tőkekövetelmény-szabályozás irányába. A dokumentum rövid távra még elutasította a teljes körü hitelkockázati modellezés szabályozási célra való elfogadását, azonban hosszabb távon lehetségesnek tartotta az intézmények saját belső hitelkockázati modellezésén alapuló szabályozási tőkekövetelmény elöírását. A dokumentum leszögezte azt is, hogy a Bázeli Bizottság elkötelezett amellett, hogy a 
szabályozási tőkekövetelmény számítása a korábbiaknál sokkal kockázatérzékenyebb legyen, oly módon, hogy a bankok saját, belső minősítési rendszereit is felhasználja a tőkekövetelmény meghatározásához. Vagyis, bár a szabályozás nem engedte meg, hogy a bankok a saját fejlesztésű hitelkockázati modelljeik alapján határozzák meg a szabályozói tőkekövetelményüket, de azt igen, hogy a belső minősítési rendszerük alapjául szolgáló legfontosabb paramétereiket maguk modellezék. A szabályozásnak ez a jellemzője a konzultációs periódus során nem változott, végleges változata (BCBS [2004]), akárcsak európai megfelelöje, a tőkemegfelelési irányelvek (Capital Requirement Directives, $C R D)^{3}$ megengedte a bankoknak, hogy a szabályozási tőkeszükséglet számítása során belső kockázatkezelési modelljeikkel határozzák meg a legfontosabb hitelkockázati paramétereket, feltéve, hogy az alkalmazott módszereket a felügyeleti hatóság elfogadja és jóváhagyja.

A szabályozási célra használandó hitelkockázati modellt - a bankok legjobb kockázatkezelési gyakorlatának összegzése alapján - a Bázeli Bizottság fejlesztette ki. Azon bankok számára, amelyek fejlett, de nem a legfejlettebb kockázatkezelési gyakorlatot folytatták, a szabályozás lehetővé tette az úgynevezett belső minősítésen alapuló alapmódszer (Foundation Internal Rating Based Approach, alap-IRB) használatát, vagyis azt, hogy a szabályozói modellnek kizárólag a legfontosabb paraméterét, az ügyfél nemteljesítésének a valószínűségét (probability of default, $P D$ ) saját maguk becsüljék, míg a többi paramétert a szabályozás határozta meg. A legfejlettebb kockázatkezelési rendszert alkalmazó bankok nemcsak a nemteljesítési valószínűséget, de a szabályozói modell több paraméterét [a nemteljesítéskori veszteségrátát (loss given default, LGD), a nemteljesítéskori kitettség értékét (exposure at default, EAD) és a kitettség nemteljesítéskori lejáratát (maturity, $M$ )] is maguk becsülhették az úgynevezett belső minősítésen alapuló fejlett módszer (Advanced Internal Rating Based Approach, fejlett IRB) keretében.

A szabályozási hitelkockázati modell egy egytényezős modell, amelyben a kockázati tényező az eszközök nemteljesítővé válásának korrelációs koefficiense egy adott portfóliószegmensen belül, s ez a portfóliószegmens rendszerkockázatát (nem diverzifikálható kockázatát) fejezi ki. Minél nagyobb a modellben a beépített korrelációs koefficiens, annál nagyobb a portfólióba tartozó ügyfelek együttes nemteljesítésének bekövetkezési valószínüsége, azaz a modell által elöírt tőkekövetelmény. Ennek megfelelően mind a modellbe beépített korrelációs koefficiens, mind a modell bankok által becsült vagy a szabályozó által elöírt többi paramétere jelentős hatással van a szabályozói tőkekövetelmény nagyságára.

A bankok lobbiereje a szabályozási paraméterek csökkentése érdekében már a Bázel-II. szabályozás konzultációs periódusában is igen erőteljes volt. Így például a korai konzultációs dokumentumokban a fedezetlen vállalati hitelek alap-IRB szerinti használatához tartozó szabályozói nemteljesítéskori veszteségráta (LGD) 50 százalék, míg a beépített lejárati idő három év volt (BCBS [2001]), s ez a konzultációs periódus végére 45 százalékra, illetve 2,5 évre csökkent, ami számottevően mérsékelte a modell alapján számított tőkekövetelményt. A kockázati tényezőként használt

\footnotetext{
${ }^{3}$ 2006/48/EK és 2006/49/EK irányelvek.
} 
korrelációs koefficiens portfóliószegmensek szerinti értékeinek meghatározásához a G10 országok felügyeleti adatgyüjtése mellett durva becsléseket alkalmaztak, ami erősen esetlegessé tette annak szintjét. Ezt maga a Bázeli Bizottság is elismerte az IRB-függvényt magyarázó dokumentumában (BCBS [2005] 12. o.), amikor leírta, hogy az alkalmazott korrelációs koefficiens két igen fontos tulajdonsága az empirikus tények mellett intuíciókon is alapult. Az egyik ilyen tulajdonság, hogy a korreláció a nemteljesítés valószínűségének növekedésével csökken, a másik pedig, hogy a vállalati méret növekedésével emelkedik. A konzultációs periódus során a korrelációs koefficienst két esetében is csökkentették: a rulírozó lakossági hitelek kitettségek és az egyéb (nem jelzálog és nem rulírozó) lakossági kitettségei esetében. Ellenpéldát - vagyis olyan esetet, amikor bármilyen paramétert növeltek volna - nem találunk a többéves konzultációs periódusból.

A Bázel-II. kockázatalapú tőkekövetelményének bevezetésével kapcsolatban már a konzultációs időszak elejétől fogva megfogalmazódott az a kritika is, hogy erősen prociklikus lehet a tervezett szabályozás. Számos olyan tanulmány született ebben az időszakban, amely amellett érvelt, hogy az új szabályok nem fogják erősíteni a bankok eredendően prociklikus viselkedését (Lindquist [2004], Ayuso és szerzőtársai [2004], Gambacorta-Mistrulli [2003], Catarineu-Rabell és szerzötársai [2003]), míg más elemzések a szabályozás erősen prociklikus jellegét hangsúlyozták (Danielsson és szerzötársai [2001], Segoviano-Lowe [2002], Danielsson-Shin [2003], Griffith-Jones-Spratt [2003], Goodhart és szerzőtársai [2004], Király-Mérő [2004]). A viták eredményeként két, nem túl erős anticiklikus elem került beépítésre a szabályozásba: a cikluson átívelő nemteljesítési valószínűség (PD) számításának az elve és a szabályozás által elfogadott biztosítékok csökkenő értékének feltételezésével számított nemteljesítéskori veszteségráta (az úgynevezett downturn LGD) előírása. A két elem azonban nem volt meghatározó tényezője a Bázel-II. szabályozásnak, sokkal inkább csak ,jókívánságként”, semmint erős anticiklikus elemként kerültek bele. Meg kell azt is jegyezni, hogy a cikluson átívelö nemteljesítési valószínűség számítása, bár valóban anticiklikus elem, nyilvánvalóan alulbecsli a válságidőszakok nemteljesítését, és így a tőkekövetelményt is. A szabályozás a modell eredményeinek felskálázásával sem kezelte mindezen modellezési bizonytalanságokat, hiszen a modellbe beépített hatszázalékos szorzó inkább csak szimbolikusnak volt tekinthetö. Tehát a Bázel-II. egyezmény kidolgozási szakaszában a bankok szabályozási tőkekövetelményt minimalizáló, a részvényesek magánérdekét szolgáló tőkeoptimalizáló törekvése jelentős mértékben befolyásolhatta a szabályozási tőkekövetelmény nagyságát, ami több esetben erősebbnek bizonyult, mint a magasabb tőkeszint elöírásával biztosítható, nagyobb pénzügyi stabilitás közérdeke.

\section{A kockázatalapú szabályozás kockázatai}

A hitelezési kockázatok banki modelleken alapuló szabályozási tőkekövetelményének elöírásával kapcsolatban három kockázati tényezőt különíthetünk el: 1. a modellek megfelelőségének kockázata, 2. a szabályozás által elfogadott modellek pontosságának és megfelelö, egységes implementálásának kockázata és 3. az ösztönzési 
problémákból fakadó kockázatok. A szakirodalom az 1. és 2. kockázattípust egyaránt modellezési kockázatnak hívja, azonban a modellkockázat elemzésekor bizonyos szerzők a modellek elvi megfelelőségére, míg mások a pontatlanságból és a nem megfelelő implementációból fakadó kockázatokra helyezik a hangsúlyt.

E tanulmány a kétfajta modellezési kockázatot elkülönülten, megkülönböztetett jelentéstartalommal vizsgálja. A modellek megfelelőségének kockázata azt jelenti, hogy a modellek egyáltalán nem képesek megfelelően leírni a kockázatokat, és így a használatukon alapuló szabályozási tőkekövetelmény nem alkalmas a bankok potenciális veszteségének fedezésére. A modellek megfelelőségének hiányából fakadó kockázatokat jelenlegi tudásunk szerint nem lehet a modellek javításával kiküszöbölni, mivel ma még egyáltalán nem állnak rendelkezésre adekvát hitelkockázati modellek. Ettől az értelmezéstől megkülönböztetve, a modellek pontosságának és megfelelő implementációjának hiányából fakadó kockázatok egyrészt abból fakadnak, hogy a modelleknek nem kellően pontos a magyarázó és előrejelző erejük, másrészt abból, hogy a bankok a modelleket nem egységesen implementálják. Ezzel nemcsak a versenysemlegesség elvét sértik, hanem az implementálás során alkalmazott „innovatív” módszerek segítségével a szabályozás elvi elvárásától elmaradó tökeszinttel is képesek megfelelni a szabályozás betüjének. A modellkockázatnak ez az értelmezése a modellek fejlesztésével és az implementációra vonatkozó elöírások pontosításával számottevően csökkenthető.

A modellek megfelelőségével kapcsolatos fenntartások már a 2000-es évek legelején megfogalmazódtak (lásd például Danielsson és szerzőtársai [2001]). Ahogy azt Danielsson [2008] hangsúlyozza:

„Ezek a modellek hasznosak a gyakran bekövetkező, kis események mérésére, de nem alkalmasak a rendszerkockázati szempontból fontos eseményekére." (Danielsson [2008] 1. o.)

A szerző azzal érvel, hogy a modellek összetettsége és bonyolultsága nem jelenti azok megfelelö minőségét, hiszen a fizika szabályai nem hasonlítanak a pénzügyi folyamatok szabályaihoz, mert az utóbbiak sokkal komplexebbek. A modellek alkalmatlanságának okát Danielsson-Shin [2003] a kockázatok endogén természetében látja, vagyis abban, hogy a pénzügyi rendszert érintő sokkok - különösen válságidőszakokban - nem külső adottságként jelentkeznek, hanem magán a pénzügyi rendszeren belül generálódnak. A kockázatok endogén jellege mellett Danielsson [2008] a modellekhez használt feltételezések és adatok eredendően rossz minőségét is hangsúlyozza. Mivel a modellek törvényszerüen számottevően leegyszerüsítik a kockázat szempontjából releváns tényezőket, az újonnan felépülő vagy a nehezen modellezhető kockázatok könnyen a modell értelmezési tartományán kívülre kerülnek. Danielsson [2008] arra is rámutat, hogy mivel a modellezéshez használt adatok minősége az idő múlásával is számottevően változhat, a historikus adatok használatára épülő modellek megfelelősége eleve megkérdőjelezhető. Ezeket a megállapításait bebizonyította mind a piaci kockázati modellek, mind a gyenge minőségü, úgynevezett szubprime hitelek kockázatosságának mérésére használt hitelkockázati modellekre. Nézőpontja szerint a modellek célja az, hogy maximalizálják az egységnyi tökével vállalható banki kockázatok szintjét, vagyis az, hogy olyan módszertant adjanak, amely 
„biztonságossá” teszi a bankok számára a kockázati kitettségek növelését a tökéhez képest, így a modellek fejlesztésének legjobb gyakorlata tulajdonképpen nem más, mint versengés a lehetö legkisebb tökeszintért (race to the bottom).

Greenspan [2008] nagyon hasonló véleményt fogalmazott meg: rámutatott arra, hogy a banki kockázatkezelés legfőbb célja a kockázattal korrigált tőkemegtérülés (RAROC) növelése, ami erösen ösztönzi a buborékok fújását, az eufóriákban való részvételt. A modellek azonban nem képesek előre jelezni a ciklusok fordulópontjait, mivel a fordulópontok mindig a piaci jelenségekre adott irracionális emberi válaszreakciókon alapulnak, amit Greenspan a „hiányzó magyarázó változónak” hív. Azzal érvelt, hogy az eleve nem megfelelő inputok biztosan aláássák a modellek megbízhatóságát. Véleménye szerint a modellek eredményének mesterséges megváltoztatása feltétlenül szükséges ahhoz, hogy ezt a hiányzó magyarázó változót valamelyest pótolni lehessen. Hangsúlyozta azonban, hogy a modellek eredményének változtatása annak implicit beismerése, hogy a modellek nem megfelelök.

Az előző véleményeket úgy foglalhatjuk össze, hogy a modellek normál piaci körülmények között jól segítik a bankok kockázatkezelését, segítenek a RAROC optimalizálásában. Ellenben még a legjobb modellek sem képesek a pénzügyi turbulenciák megfelelő kezelésére, a pénzügyi válságok modellezhetőségének hiánya miatt, mert a ciklusfordulópontok nem modellezhetők, mivel a kockázatok a rendszeren belül generálódnak, vagyis endogének. Az endogén kockázatok - technikai értelemben a veszteségek együttes bekövetkezése miatt extrém módon megnövekedett korrelációt jelentenek, ami egyhez közeli korrelációs koefficienst feltételezne az alkalmazott modellekben, ami viszont normál időkben állítana a bankok számára értelmetlennek tűnő magas tőkekövetelményt. A bázeli szabályozási keretrendszerben (BázelII.-ben bevezetve, de ez a tényező nem változott a válság utáni szabályozási módosítások Bázel-III. rendszerében sem) az IRB-modellekben a vállalati és az állami kockázati kitettséget hordozó eszközportfólióban 24 százalék a legmagasabb korrelációs együttható, míg a lakossági szegmensben 16 százalék.

Mivel az IRB-modell szerint minden eszközportfólióban a magasabb nemteljesítési valószínűségekhez (PD-khez) alacsonyabb korrelációs együttható tartozik, a $\mathrm{PD}$ növekedésével jellemezhető időszakokban a nagyobb PD miatti tőkekövetelménynövekedést ellensúlyozza a nagyobb PD-hez tartozó kisebb korrelációs együttható tőkekövetelményt csökkentő hatása. A korrelációs együtthatókkal kapcsolatban a Bázel-III. egyetlen változtatása az, hogy a nagyméretű pénzügyi intézmények, valamint a nem szabályozott szférába tartozó pénzügyi intézmények esetében a korábbi korrelációs együtthatót megszorozták 1,25-tel. Ebben az esetben a maximális korrelációs együttható 30 százalék lett. Vagyis - a piaci kockázatok mérésére alkalmazott VaR-modellekhez hasonlóan - az IRB-modellek is a „békeidők” tőkekövetelményét képesek jól mérni, nem pedig azokét a turbulens időszakokét, amelyekben a korrelációk extrém módon megnövekszenek. Márpedig a betétesek pénzének védelmére éppen ezekben az időszakokban van a legnagyobb szükség. Ez az a pont, ahol a makroprudenciális szabályozás és a kockázatalapú szabályozás kérdésköre összekapcsolódik: a cikluson átívelő PD és a csökkenő fedezeti értékek feltételezésével számított nemteljesítéskori veszteségráta (LGD) előírása, valamint - az elvileg - a 
rendszerkockázatokat kifejező korrelációs együttható ${ }^{4}$ ellenére az IRB-modell eredendően mikroprudenciális szemléletű. Ennek tükrében nem véletlen, hogy a BázelIII. keretrendszerbe integrált makroprudenciális szabályozóeszközök jellemzően az IRB tőkekövetelményén kívüli eszközöket jelentenek: az IRB-alapú tőkekövetelményen felül határoznak meg különbözö tőkepuffereket annak érdekében, hogy a banki tőke a rendszerkockázatokkal szemben is védje a betétesek pénzét.

A bankok képviselöi, de több szabályozó- és felügyelőhatóság is, az előzőknél szűkebb értelemben használják a modellkockázat fogalmát, kizárólag a modellek kellö pontosságának és egységes implementálásának hiányából fakadó kockázatokat értik rajta. Azt feltételezik, hogy a hitelkockázati modellek alapvetően megfelelő szabályozóeszközök, de szükség van a finomításukra, valamint az implementálásukra vonatkozó egységes elvek és eljárások kidolgozására. Ebben a megközelítésben a kockázatalapú szabályozás legnagyobb hiányossága, hogy a nem megfelelő modellezési gyakorlat, illetve a nemzeti felügyeleti hatóságok eltérő modellvalidációja aláássa a bankpiaci versenysemlegességet. 2015-ben az Európai Bankhatóság az IRB-rendszer jövőjéről kezdeményezett konzultációs folyamatot (EBA [2015]). Vitaanyagában nem kérdőjelezte meg az IRB-modellek alapvető megfelelőségét, sőt kiindulópontként leszögezte, hogy azok általánosságban a szabályozás jó fejlődési irányát jelentik, csak a modellek pontosságából és eltérő implementációjából fakadó kockázatokra helyezte a hangsúlyt. A konzultáció célja ennek megfelelően - a címben jelzett kérdésfeltevéssel ellentétben - nem általánosságban az IRB jövőjéről szólt, hanem arról, hogy hogyan lehetne a modellhasználatot a jövőben pontosabbá, egységesebbé tenni. Megközelítésének megfelelően a dokumentum 25, erősen technikai jellegü kérdést fogalmazott meg a konzultáció kiindulópontjaként.

Az EBA a konzultációs kezdeményezésre 28 választ kapott, közülük 22 érhető el nyilvánosan. Nem meglepő módon a konzultáció eredményeit összegző dokumentum (EBA [2016]) ugyancsak a fent említett megközelítést tartalmazza. A válaszadók hangsúlyozzák, hogy az IRB-módszer alapvetően jó. Azt elismerik ugyan, hogy az IRB-módszer különböző implementálása szabályozási arbitrázsra ad alkalmat, de hangsúlyozzák, hogy ez a hátránya a kevésbé kockázatérzékeny szabályozásnak is megvan, miközben az IRB számos előnye miatt sokkal jobban működik, mint a nem kockázatérzékeny rendszerek, elsősorban, mert hatékonyabb.

A banki modellek alkalmazásának különbözőségéből fakadó kockázatok csökkentése érdekében mind a Bázeli Bizottság, mind az EBA áttekintette a bankok által alkalmazott kockázati súlyozás konzisztenciáját. A Bázeli Bizottság az IRBmódszert használó 35 nemzetközileg aktív nagybank lakossági és kis- és középvállalati eszközeinek súlyozását elemezte (BCBS [2016a]). Azt találta, hogy az átlagos kockázati súlyok a lakossági jelzáloghitelek esetében bankonként 5,2 és 81,1 százalék között mozogtak, 16,9 százalékos mediánnal, míg a kis- és középvállalatokra

\footnotetext{
${ }^{4}$ A modellnek az a sajátossága, hogy a nemteljesítési valószínűség (PD) növekedésével jellemezhető időszakokban csökkenő korrelációs együtthatót alkalmaz, még mikroprudenciális szemléletben is megkérdőjelezhető, hiszen például a rossz hitelezési gyakorlat a nem várt (vagyis tőkével fedezendő) veszteségek korrelált növekedését okozhatja. Ilyen esetben minél nagyobb a PD (minél rosszabb a bank általános hitelezési gyakorlata), annál nagyobb a bukások esélye.
} 
vonatkozó kockázati súlyok 46,2 százalék és 91,2 százalék között alakultak, 59,8 százalékos mediánnal, ami extrém módon nagy eltéréseket jelent, és nyilvánvalóan nem magyarázható kizárólag a bankok kockázati profiljából fakadó tényezőkkel. Az EBA felmérése (EBA [2017a]) 22 EU-tagállam 102 IRB-módszert alkalmazó bankjára terjedt ki. Ez az elemzés - összhangban a Bázeli Bizottság által kapott eredményekkel - szintén azt találta, hogy a bankok által számított nemteljesítési valószínüségek nagymértékben különböznek egy-egy adott kitettségi osztályon belül. A felmérés összegezése azonban kiemeli, hogy ez az eltérés nemcsak a PD-modellek különbözőségéből fakadhat, hanem a felmérésben részt vevő bankok különböző kockázati profiljából is. Ezért is lehet kiemelt jelentősége a modellek összehasonlítása szempontjából annak a hipotetikus portfólióelemzésnek, amelyet ugyancsak az EBA készített (EBA [2017b]). Ennek keretében a több mint 100 részt vevő banknak az alacsony nemteljesítési valószínűségű portfóliószegmensekre ${ }^{5}$ kellett az adott bank saját kockázati modelljével kiszámolnia - ugyanarra a hipotetikus portfólióra számolva -, hogy mekkora lenne a bank teljes kockázati költsége, vagyis az értékvesztés és a tőkeköltség összege. A felmérés eredménye azt mutatta, hogy a teljes kockázati költség ugyanarra a hipotetikus portfólióra vonatkozóan 8 százalék és 147 százalék között mozog. Ennek az extrém nagy különbözőségnek 61 százaléka indokolható a különféle bankspecifikus kockázati tényezőkkel, míg 39 százaléka kizárólag a modellezési gyakorlat banki sajátosságaival magyarázható.

Az ösztönzési problémák a modellkockázatok mindkét típusához, vagyis a modellek megfelelőségének mint pontosságának és implementálásának kockázatához köthetők. A modellek megfelelőségének kockázatát már Danielsson [2008] és Greenspan [2008] is összekapcsolta a modellhasználat lehetőségéből fakadó ösztönzési problémákkal. Mindketten hangsúlyozták, hogy a bankok érdeke a RAROC növelése, ami messze nem esik egybe a pénzügyi stabilitás közérdekével. A modellek megfelelőségének kockázatát az ösztönzési problémákkal és a Bázeli Bizottság válságot követő szabályozási csomagjával együtt elemezve Hellwig [2010] „a kockázat mérhetőségének illúziója” kifejezést használta (6. o.). Véleménye szerint, a Bázeli Bizottság hibát követ el, amikor azt gondolja, hogy a kockázatalapú szabályozás hiányosságai olyan technikai problémák, amelyek javíthatók. Azzal érvel, hogy a bankok bonyolult kockázatkezelési technikáit a banki kockázatkezelési szakemberek fejlesztették ki, annak érdekében, hogy a lehető legkisebb, a szabályozás számára még éppen elfogadható tőkeszint mellett müködhessenek. Kizárólag a bankoknak van pénze arra, hogy megvásárolják a legjobb modellező szakembereket, a piacon más szegmensekben elérhető fizetést messze meghaladó javadalmazással - azért, hogy tőketakarékos hitelkockázati modelleket fejlesszenek ki. A felügyeleti hatóságok pedig a banki szakma mögött kullognak a modellek validációja során, vagyis a modellfejlesztés motorja mindig a bankok magánérdeke. Ezt a logikát követi Admati [2016] is, amikor a Bázel-III. szabályozási rendszert „elmulasztott lehetőségnek” nevezi, mivel nem növeli meg kellő mértékben

\footnotetext{
${ }^{5}$ Ezek: a szuverén kockázatot hordozó portfóliószegmensek, a pénzügyi intézmények szegmense és a nagyvállalati szegmens.
} 
a banki tökekövetelményt, ami pedig a válság alatt kritikus módon kevésnek bizonyult. Admati ebben a cikkében is - akárcsak Hellwiggel közösen írt könyvében (Admati-Hellwig [2013]) - amellett érvel, hogy a bankoknak, más iparágakban tevékenykedő vállalkozásokhoz hasonlóan, sokkal nagyobb mértékben kellene a saját tőkéjükre támaszkodniuk üzletmenetük finanszírozása során, részben profitjuk visszaforgatása, részben pedig új részvények kibocsátása segítségével. Az alacsony tőkekövetelmény megengedi, hogy a bankok magas tőkeáttételt (leverage-t) építsenek fel, azaz tevékenységük nagy részét ne saját tőkével finanszírozzák, ami a tőketulajdonosok egységnyi tőkére jutó nyereségét és veszteségét is megtöbbszörözi. Ennek következtében jó időkben kiemelkedően magas profitra tehetnek szert, míg rossz időszakokban könnyen elveszthetik a befektetésüket. Azok a közvetett és közvetlen garanciák azonban, amelyek a betétbiztosítási rendszerben és az esetleges állami bankmentő csomagokban testesülnek meg, erősen csökkentik ezt a veszteség irányába mutató kockázatot, miközben nem csökkentik a jó időszakok nyereségét. Ezért is olyan nagy a bankok kockázati étvágya, ezért építenek fel a szabályozás keretén belül minél nagyobb tőkeáttételt, és ezért invesztálnak sokat a kockázatokat mérő modellek fejlesztésébe.

A modellek pontosságának és implementálásának kockázata is szoros kapcsolatban áll az ösztönzési problémákkal. Számos tanulmány mutatja ki, hogy azok a kockázati súlyozási rendszerek, amelyeket a bankok maguk építenek ki, túl alacsony súlyokat használnak, mert a modellek eredménye erősen lefelé torzít a bankok érdekének megfelelöen (lásd például Acharya és szerzőtársai [2014], Mariathasan-Merrouche [2014], Behn és szerzötársai [2016], Calomiris [2017], Plosser-Santos [2014]). Ennek megfelelően a modellek pontossága és megfelelő implementálási gyakorlata erősen megkérdőjelezhető. Néhány tanulmány közvetlenül kapcsolja össze a bankok kockázati modellezési gyakorlatát és a kockázatalapú szabályozás ösztönzési struktúráját, és azt nézi, hogy mekkora a banki PD-k torzítása ennek következtében. Plosser-Santos [2014] az Egyesült Államok szindikált hiteleinek adatain azt nézte meg, hogy egy-egy szindikált hitelszerződés esetében, amikor ugyanannak a hitelfelvevőnek több bank egy időben adott hitelt, hogyan különbözött az egyes bankok modelljei által számított PD-k értéke. Azt tapasztalták, hogy a banki PD-k között jelentős eltérés mutatkozik, és hogy a gyengébb tökehelyzetü bankok modelljei rendre alacsonyabb PD-t adnak, vagyis esetükben a modellek alábecsülik a kockázatokat.

Mariathasan-Merrouche [2014] a kockázattal súlyozott eszközérték összes eszközhöz viszonyított arányát vizsgálta 21 OECD-ország 115 IRB-módszert használó bankjának adatain - közvetlen azelőtt és azután, hogy a bank az IRB-módszer használatára vonatkozó felügyeleti engedélyt megkapta. A szerzőpáros eredményei egyértelmüen arra mutatnak, hogy a bankok által számított hitelkockázati szint az IRBengedély megszerzését követően csökken, vagyis a modelleket stratégiailag használják arra, hogy manipulálják az alkalmazandó kockázati súlyozást. A vizsgálat azt is kimutatta, hogy a gyengébb tőkehelyzetü bankok esetében a validálás előtti és utáni kockázati súlyozás között nagyobb az eltérés.

Behn és szerzőtársai [2016] német adatokat elemezve jutott hasonló eredményre. A szerzők konkrét hitelekhez kapcsolódó PD-értékeket hasonlítottak össze olyan 
bankok esetében, amelyeknél az IRB-módszer még validálás alatt állt, illetve olyanokéban, amelyek már IRB-t használtak. Azt tapasztalták, hogy ugyanannak a hitelfelvevőnek ugyanabban az időpontban a már IRB-t használó bankok jóval alacsonyabb nemteljesítési valószínűséget tulajdonítanak, mint azok a bankok, amelyek még az IRB-rendszerük felügyeleti elfogadására várnak. Azt is kimutatták, hogy az IRB-t használó bankok alacsonyabb nemteljesítési valószínüségeihez összességében magasabb tényleges veszteség tartozik, mint a magasabb nemteljesítési valószínüséget mérő, validálás alatt álló bankok tényleges vesztesége. Ez éppen ellenkezője annak, ami a kockázatalapú szabályozás eredeti elvi célja, hogy a magasabb kockázatvállaláshoz magasabb tőkeszint társuljon. A szerzők a kapott eredményeket azzal magyarázzák, hogy a bankok alapvető érdeke a szabályozási tőkekövetelmény alacsonyan tartása, ami arra ösztönzi őket, hogy alulbecsüljék az ügyfelek nemteljesítési valószínüségét.

Az a munka, amelyet az Európai Bankhatóság és más szabályozóhatóságok végeznek, korlátozhatja a bankok magánérdekéből fakadó, a kockázatokat alábecslő „innovatív” modellek használatát, a modellek manipulációját. A bankoknak azonban mindig is több erőforrása volt (lesz) a modellek fejlesztésére, mint a szabályozóhatóságoknak, mivel ez a ráfordítás teljes mértékben az érdekeiket szolgálja. Körülbelül úgy jellemezhetjük ezt a helyzetet, mint a programozók és a hackerek vagy a zárfejlesztők és a „mackósok” versenyét. A banki modellezők és a szabályozók folyamatos versenyben állnak egymással, mindkettő igyekszik a másik szándékát kikémlelni és megérteni, hogy lépéselőnyre tehessen szert. A kockázatalapú szabályozás ellenben nem képes hatékonyan szolgálni a pénzügyi stabilitást mint közérdeket, még abban a feltételezett esetben sem, ha sikerülne a modellek pontosságának hiányából és implementációjának különbözőségéből fakadó kockázatokat teljesen kiküszöbölni, amit a gyakorlatban igen nehéz elképzelni. Következésképpen, a bankok magánérdek-érvényesítésének visszaszorításához arra van szükség, hogy a szabályozás ne csak kockázatalapú elemekből épüljön fel, legyenek ennek negatív ösztönzési hatásait ellensúlyozó eszközei is.

\section{A kockázatalapú és a nem kockázatalapú elemek keveréke a globális pénzügyi válság utáni szabályozási eszköztárban}

Az előző részben leírtakkal összhangban a Bázeli Bizottság a Bázel-III. szabályozás szükségességének indoklásakor úgy fogalmaz, hogy

„....éteznek a kockázati súlyok minimalizálására irányuló ösztönzők a belső modellek használatához kapcsolódóan. Ezen túlmenően bizonyos eszköztípusokat - mint például az alacsony nemteljesítési valószínűségekkel jellemezhető eszközöket - nem lehet megbízhatóan és robusztusan modellezni. A reformok korlátozásokat vezetnek be azokra a becslésekre vonatkozóan, amelyeket a bankok a szabályozói tőkekövetelmény megállapítására szolgáló belső modelljeikhez használnak, és néhány esetben még meg is szüntetik a modellhasználat lehetőségét." (BCBS [2017b] 1. o.) 
A hitelkockázati tőkekövetelmény számításával kapcsolatban a Bázel-III. háromféle korlátozást tartalmaz, amelyekről elmondható, hogy a modellek használatát korlátozzák. Ezek: 1. a kockázati súlyozás nélküli tőkeáttételi ráta (leverage ratio), 2. minimális küszöbértékek meghatározása a modellek bizonyos inputjaira (input floors) és eredményének felhasználhatóságára (output floor) vonatkozóan, és 3. magának az IRB-módszer használatának a korlátozása néhány portfóliószegmensre és kockázati kitettségi kategóriára vonatkozóan. A következőkben ezt a három módszert elemezzük, és arra keressük a választ, hogy vajon ezekkel az eszközökkel valóban hatékonyan csökkenthetők-e a modellek pontosságával és implementálásával kapcsolatos kockázatok, és ezek az eszközök hogyan változtatják meg a modellek használatához kapcsolódó ösztönzési struktúrákat.

\section{A tőkeáttételi ráta szabályozása}

A szakirodalom utólagosan a globális pénzügyi válságot megelőző időszak egyik legfontosabb sebezhetőségi okaként a nagyon magas banki tőkeáttételt azonosította. Ahogy azt Acharya-Schnabl [2009] kimutatta, a magas tőkeáttétel fó oka az értékpapírosításhoz kötődő szabályozási arbitrázs volt, abban az esetben is, amikor a bankok hitelportfóliójukat értékpapírosítás után külső befektetőknek adták el, és akkor is, amikor hitelezés helyett $A A A$ minősítésű CDO-kat és CLO-kat vásároltak. Ezt a jelenséget tőkeáttételi játszmának (leverage game) nevezik. És valóban, ez a szabályozóhatóságok és a szabályozott intézmények folyamatos játszmája volt. Utólagosan nem is annyira a konkrét arbitrázstechnika az érdekes, hiszen az újabb és újabb arbitrázstechnikák kifejlesztése a bankok eredendő érdeke. A kockázatalapú szabályozási környezetben olyan új termékek kifejlesztése, amelyeknek az éppen érvényes szabályozás alábecsüli a kockázatait, és így a termékek potenciális veszteségének fedezésére szolgáló tőkekövetelményt is, azonnali profitot jelentenek a bank számára. A szabályozási arbitrázs ellensúlyozására azonban Acharya-Schnabl [2009] nem az áttételi ráta szabályozásának szigorítását javasolja, ${ }^{6}$ hanem azt, hogy átfogó indikátorrendszeren alapuló felügyeleti megítéléssel próbálják megelőzni a szabályozói tőke arbitrázsát. Európában, ahol az értékpapírosítás kevésbé volt fejlett, mint az Egyesült Államokban, volt még egy speciális oka is a magas tőkeáttételek felépülésének: az euróövezeten belül nulla kockázati súlyozást lehet használni az euróban denominált szuverén kockázati kitettségekre - így például a görög államkötvényekre -, amivel a bankok magas hozamra, de tökelekötés nélkül tudtak befektetni.

Admati [2016] szintén azt hangsúlyozza, hogy a szabályozási arbitrázs a kockázati súlyozáson alapuló rendszerek elkerülhetetlen velejárója, ami - az alacsony sajáttőkekövetelménnyel együtt - rendkívül magas tőkeáttételhez vezethet. Ô a szabályozási arbitrázs három könnyü módját sorolja fel. Ezek:

- a banki modellek figyelmen kívül hagyják a ritka események kockázatát (tail-risk);

\footnotetext{
${ }^{6}$ Az Egyesült Államokban mindig létezett áttételiráta-szabályozás, szemben az EU-val, ahol ezt EUszintű szabály nem írta elő, és a tagállamok saját hatáskörben sem alkalmazták.
} 
- a bankok képesek az IRB-rendszeren belül manipulálni a kockázati súlyokat és ezen keresztül a tőkekövetelményt;

- a szabályozók néhány kitettségi osztályt kedvezményesen kezelnek, mint például a szuverén kockázatokat. ${ }^{7}$

Mivel a bankok profitérdeke nem a nagyobb stabilitást biztosító alacsonyabb tőkeáttétel, hanem a nagyobb profit, Admati-Hellwig [2013] 30 százalékos - kockázatokkal nem súlyozott - szabályozási tőkekövetelmény bevezetését javasolja. Javaslatuk szerint ebből 20 százalék lenne a súlyozatlan sajáttőke-rész, további 10 százalék puffert pedig a banki profit visszaforgatásával kellene képezni, hasonlóan a Bázel-III. szabályozás tőkemegörzési pufferének képzési mechanizmusához.

A globális pénzügyi válság utáni bankszabályozási reform már nem kerülhette meg a modellhasználatból fakadó kockázatokat, így a súlyozatlan tőkeáttételre vonatkozó szabályozást, kiegészítő jelleggel, beemelte a szabályozás eszköztárába. Azonban ennek mértéke messze elmarad az Admati-Hellwig [2013] által javasolttól, mindöszsze a mérlegen belüli és kívüli eszközök súlyozatlan értékének 3 százalékát írja elö. Sőt még ezt sem a bank saját tőkéjével kell teljesíteni, hanem az úgynevezett alapvetö tőkeelemekkel (Tier 1 capital), ami már bizonyos mennyiségü hibrid kötvény, hitel vagy speciális részvényelem tőkekénti figyelembevételét is megengedi (BCBS [2014a]). A Bázel-III. végső változatában ( $B C B S$ [2017a]) ezt még egy extra tőkeáttételi puffer is kiegészíti a globálisan rendszerszinten jelentős bankok (Globally Systematically Important Banks, G-SIB) számára. ${ }^{8}$

A pufferkövetelmény az érintett bankok kockázattal súlyozott eszközértékei alapján számított G-SIB-tőkepuffereinek az 50 százaléka, és majd csak 2022-től kell megképezni. A tőkeáttételi szabályozás ebben a formájában azon bankok számára, amelyek nem tartoznak a harminc G-SIB bank közé, alapvetö tőkeelemeik nagyságánál 33,3-szor nagyobb mérlegen belüli és kívüli eszközállomány felépítését engedi meg, ami - tekintettel az alapvető tőkébe beszámítható hibridekre - a saját tőkéhez viszonyítva 44,33-szoros limitet jelent. Ez nyilvánvalóan nem ellensúlyozhatja a szabályozói arbitrázsra való ösztönzést. A Pénzügyi Stabilitási Tanács (Financial Stability Board, FSB ${ }^{10}$ legfrissebb, 2017. novemberi listája szerint a harminc G-SIB bank közül 17-nek mindössze egyszázalékos a G-SIB-pufferkövetelménye, vagyis ez fél százalékkal, három százalékról 3,5 százalékra növeli a rájuk vonatkozó tőkeáttételirátakövetelményt, így még ezek a bankok is a saját tőkéjük 38-szorosának megfelelő mérlegen belüli és kívüli eszközállományt tudnak felépíteni (FSB [2017]). Jelen állapot szerint a legnagyobb (2,5 százalékos) G-SIB-tőkepuffer kizárólag a J. P. Morgan

\footnotetext{
${ }^{7}$ Itt nemcsak a korábban említett, EU-n belüli, a teljes euróövezetre adott kedvezményekről van szó, hanem arról is, hogy a hazai pénznemben denominált szuverén adósságok kezelése általánosságban is kedvezményes.

${ }^{8}$ Jelenleg harminc bank tartozik ebbe a kategóriába.

${ }^{9}$ A G-SIB-puffer a bank nemzetközi rendszer-kockázatosságának mértékétől függően a kockázattal súlyozott eszközérték 1-3,5 százaléka lehet, ahol a 3,5 százalékos elöírás jelenleg még üres halmaz, de a bankok növekedésével elképzelhető, hogy a jövőben majd effektívvé válik.

${ }^{10} 2009$ áprilisában hozták létre a G20 országok, a korábbi Financial Stability Forum (FSF) nagyobb felhatalmazású utódaként, a nemzetközi pénzügyi stabilitás támogatására.
} 
Chase bankra vonatkozik, ami azt jelenti, hogy ennek az egy banknak 4,25 százalékos alapvető tőkével számított súlyozatlan áttételi rátát kell teljesítenie, ami - ha a hibrid tőkeelemek beszámíthatóságát is figyelembe vesszük - a saját tőkéhez képest még mindig 31,3-szoros eszközállomány felépítését engedi meg. Vagyis a tőkeáttételi szabályok egyáltalán nem kérdőjelezik meg a kockázatalapú szabályozás továbbélését, hiszen a Bázel-III. keretében bevezetett követelmény olyan alacsony, hogy alig korlátozza a bankokat abban, hogy idegen forrásokból finanszírozzák a tevékenységüket, nem növeli érdemben a saját tőke veszteségviselő képességét, és így nem korlátozza a bankok magánérdekének érvényesülését.

Mindemellett, a tőkeáttételiráta-szabályozás, még ha kellően szigorú is, nem lehet alkalmas arra, hogy a rendszerkockázatokat számottevő mértékben csökkentse. Ennek oka a tőkeáttételi szabályozás - a piaci áron nyilvántartott eszköztételek értékelése miatti - cikluserősítő jellege. Ahogy azt Adrian-Shin [2010] bemutatja, mind az eszközértékek növekedése, mind azok csökkenése olyan alkalmazkodási folyamatot indít be a bankok részéről, amely felerősíti a banktevékenység eredendő prociklikusságát. Az eszközök piaci áron való értékelése általános gyakorlat a bankok mérlegében lévő pénzügyi instrumentumok esetében, de a hitelek piaci áron való szerepeltetése sem elhanyagolható mértékü. Vagyis a piaci árazást használó számviteli környezet esetében a tőkeáttételiráta-szabályozás nem képes kiküszöbölni a rendszerkockázatokat, sőt magas eszközár-volatilitás esetén még fel is erősítheti azokat, mivel növekvő piaci árak mellett a tőkekövetelmény nő, csökkenő piaci árak esetén pedig mérséklődik.

\section{Minimális küszöbértékek meghatározása a modellek bizonyos inputjaira és eredményének felhasználására vonatkozóan}

A modellek inputszintjéhez rendelt minimumkövetelmények és a modelleredmények felhasználhatóságának korlátozása már része volt a Bázel-II. rendszernek is. A BázelII. szabályozás az inputok esetében a vállalati és lakossági kitettségek nemteljesítési valószínűségére $(\mathrm{PD})$ minimum háromszázalékos küszöbérték alkalmazását írta elö, nulla PD-t kizárólag a szuverén kockázatok és a pénzügyi intézmények esetében lehetett alkalmazni. A Bázeli Bizottság 2016-ban kibocsátott konzultációs dokumentuma (BCBS [2016b]), majd maga a Bázel-III. csomag azonban ennél jóval több inputra határozott meg minimum-küszöbértékeket, és jellemzően megnövelte a már meglevő értékeket is. A lakossági és vállalati PD-k minimális küszöbértékét 5 százalékra emelte (a rulírozó lakossági hitelekét 10 százalékra), és néhány portfóliószegmens esetében küszöbérték-minimumokat vezetett be a nemteljesítéskori veszteségrátára (LGD-re) is. Így például az új szabályozás a fedezetlen vállalati hitelek esetében 25 százalékos, a fedezetlen rulírozó lakossági hitelek esetében 50 százalékos, míg a lakossági jelzáloghitelek esetében 5 százalékos LGD-minimum-küszöbértéket határoz meg.

A szabályozás az inputminimumok mellett limitálta a modelleredmények tőkekövetelmény-meghatározáshoz való felhasználását is. Az erre vonatkozó küszöbérték szintén része volt már a Bázel-II. szabályozásnak is azért, hogy megelőzze az akkor még teljesen új logikájú tökekövetelmény-számítás esetleges meglepetésszerü, 
hirtelen, általános tőkekövetelmény-szintet csökkentő hatását. Ezzel a szándékkal összhangban, a szabályozás eredetileg átmenetinek szánta a tőkekövetelmény minimális szintjét befolyásoló küszöbértékek (output floor) rendszerét. A Bázel-II. IRBmódszerét használó bankok számára az IRB-tőkekövetelmény minimuma a Bázel-I. szerint számított tőkekövetelmény 80 százaléka volt. A kibontakozó globális válság hatására azonban 2009-ben a Bázeli Bizottság úgy döntött, hogy tartósan megtartja a minimumértékre vonatkozó előírást (BCBS [2009]), amelyet a szakzsargon Bázel2,5-nek hív. A minimumérték szabályozói meghatározása a kockázatalapú szabályozás hatókörét úgy csökkenti, hogy megőrizi a korábbi, nem kockázatalapú szabályozás előírását mint referenciaértéket. 2014-ben a Bázeli Bizottság a minimumszint-előírásokra vonatkozó konzultációs dokumentumot adott ki (BCBS [2014b]), egyrészt arról, hogy a jövőben nem átmenetinek, hanem állandónak gondolja az output floorok rendszerét, másrészt arról, hogy milyen jövőbeli minimumrendszerben gondolkodik. Ennek lényege, hogy többé már nem a Bázel-I. jelenti a minimumszintek viszonyítási alapját, hanem a Bázel-III. keretében bevezetendő, új standard módszer, amely különösen a hitel összegéhez viszonyított alacsony értékủ jelzálogfedezetü lakossági jelzáloghitelek megnövekedett kockázati súlyozása miatt jelent nagy tőkekövetelmény-növekedést. A Bázel-III. szabályrendszer végleges változata szerint a tőkekövetelmény minimális küszöbértékének mértéke 72,5 százalék (BCBS [2017a]), vagyis az IRB szerinti tőkekövetelmény a modellalapon számított tőkekövetelmény és a standard módszer szerinti tőkekövetelmény 72,5 százaléka közül a magasabb érték, amely szabályt majd 2022-től kell alkalmazni.

A küszöbértékek minimumainak állandósítása visszalépést jelent a kockázatalapú szabályozás alkalmazásától a korábbi, kevéssé kockázatérzékeny rendszerek felé. Ezt a szemléletet sokan és erősen vitatták a konzultációs periódus során. ${ }^{11}$ A kérdés olyannyira fontos volt a bankok és néhány nemzeti szabályozóhatóság számára, hogy a szük szakmai fórumok mellett a szélesebb közvéleményt célzó szakmai sajtó és a bankok honlapja is rengeteg ellenvéleményt tett közzé a témával kapcsolatban. ${ }^{12}$ A Deutsche Bank egyenesen úgy érvelt, hogy a kötelező és állandó minimumérték alkalmazása a szabályozás startvonalára - vagyis az elavult, sokat és joggal kritizált Bázel-I. szabályok rendszerének szintjére - veti vissza a bankrendszert (Matherat [2016]). Az Európai Bankföderáció, a bankok európai érdekvédelmi szervezete pedig a minimum-küszöbértékekben látta a legfőbb prudenciális akadályát annak, hogy az EU-ban a bankok képesek legyenek a gazdasági növekedést finanszírozni (Mijs-Sabatini [2016]).

A Bázeli Bizottság minimum-küszöbértékekre vonatkozó javaslatának értékelésére és európai bevezetésének előkészítésére az Európai Parlament 2016 novemberében nyilvános meghallgatást szervezett. Ehhez elözetesen három elemzés is készült. Mind a háromnak ugyanaz volt a címe és az alcíme: „A bankok belső minősítésen alapuló modelljei - itt az idő a változásra? - A »floorok rendszere «, ahogyan azt a Bázeli Bizottság javasolta" (Resti [2016], Haselmann-Wahrenburg [2016], Huizinga [2016]).

\footnotetext{
${ }^{11}$ A Bázeli Bizottság részére küldött észrevételek a következő helyen érhetők el: https://www.bis. org/bcbs/publ/comments/d306/overview.htm.

${ }^{12}$ Lásd például Levring [2017], Verhoeven [2016], van Nieuwkerk-de Vries [2015].
} 
A három tanulmány nagyon különböző érvelés alapján eltérő következtetésekre jutott. Resti [2016] szerint a bevezetésre javasolt minimális küszöbértékek egy valódi problémára adnak hibás választ. Véleménye szerint a banki modellezési gyakorlat és a felügyeleti validálás javításával és egységesítésével a kockázatalapú szabályozás minősége számottevően javítható, ami feleslegessé teszi, hogy annak használatát további minimum-küszöbértékek bevezetésével korlátozzák.

Restihez hasonlóan Haselmann-Wahrenburg [2016] is a minimális küszöbértékek ellen érvelt, mert ez nem csökkenti a modellezéssel kapcsolatos legnagyobb problémát, nevezetesen, hogy azokat a bankok nagyon eltérően használják. A szerzőpáros véleménye szerint a tőkeáttételi rátára vonatkozó korlát az a hatásos szabályozási eszköz, amely a kockázatalapú szabályozás hiányosságait ellensúlyozza. Más, hasonló funkciójú korlátra nincs szükség. Ugyanakkor a nemteljesítési valószínűségekre mint inputra vonatkozó minimum-küszöbértékeket elfogadhatónak tartják abban az esetben, amikor kevés a rendelkezésre álló nemteljesítési adat, azért, hogy ellensúlyozzák a túlzott banki optimizmust, és ezzel is segítsék az egységes modellezési gyakorlat kialakítását.

Velük szemben Huizinga [2016] nem úgy tekint a modellek eredményének használatát korlátozó minimumértékekre, mint a banki kockázatkezelés fejlődését és hatékonyságát gátló tényezőre, hanem mint olyan eszközökre, amelyek ellensúlyozzák a bankok modellmanipulációiból fakadó alultőkésítettségét. Emellett hasznosnak tartja az IRB-modellbe beállítandó, a bankok által meghatározható paraméterek értékeire vonatkozó minimum-küszöbértékeket is, mert azok csökkenthetik a paraméterek mérési hibájából fakadó hatásokat.

Összességében elmondhatjuk, hogy a minimum-küszöbértékek erősen vitatott megítélésük ellenére nyilvánvalóan olyan szabályozási eszközt jelentenek, amelyek annál erősebben képesek a banki magánérdek visszaszorítására, minél magasabban vannak megállapítva. A minimum-küszöbértékekre vonatkozó korlátoknak egyszerre kell kellően magasnak lenniük ahhoz, hogy hatásosak legyenek, és kellően alacsonynak lenniük ahhoz, hogy ne hassanak a banki kockázatkezelés fejlesztésére való ösztönzés ellen. A standard módszer eredményéhez viszonyított 72,5 százalékos alsó küszöbérték, ami maximum 27,5 százalékos tőkemegtakarítást enged meg, elég sok teret ad arra, hogy megmaradjon a bankok ösztönzöttsége a kockázatmérés és kockázatkezelés fejlesztésére. Ugyanakkor nincs arra vonatkozó bizonyíték, hogy mekkora mozgástér az, amely elegendő erre a célra. Vajon már a 10 vagy 20 százalékos tőkemegtakarítás is elegendő lenne, vagy valóban a 27,5 százalékos szintre van szükség?

\section{Az IRB-módszer használatának korlátozása}

Az IRB-alapú tőkekövetelmény használatára vonatkozó megszorítások voltak az utolsók azon megszorítások sorában, amelyeket a Bázeli Bizottság abból a célból bocsátott konzultációra, hogy bizonyos portfóliószegmensek esetében csökkentse a kockázatalapú szabályozás hatókörét azzal, hogy ezen szegmensekben vagy egyáltalán nem engedi meg az IRB-módszer használatát, vagy csak az alap-IRB-módszert 
engedélyezi, és nem teszi lehetővé a fejlett IRB használatát $(B C B S[2016 b]) .^{13} \mathrm{Az}$ IRB-módszer használatának korlátozására vonatkozó megszorítások formálódása is igen jól példázza a bankok lobbierejét.

A Bázeli Bizottság eredeti javaslatában kizárólag a standard módszer használatát engedte volna meg a pénzügyi intézmények és a nagyvállalatok ${ }^{14}$ esetében $(B C B S$ [2016b]). Az ennél kisebb, de még mindig a nagyvállalati szegmens felső részébe tartozó vállalkozások ${ }^{15}$ számára pedig csak az alap-IRB-módszer használatát javasolta. A javaslat azon a felismerésen alapult, hogy a kevés számú nemteljesítési eseménynyel rendelkező portfóliószegmensek esetében különösen nagy a modellek pontosságának kockázata. A bankok ezt a javaslatot is erösen ellenezték ${ }^{16}$ mert csökkenti a tőkekövetelmény kockázatérzékenységét, tovább növeli a tőkekövetelményt, és a standard módszer előtérbe helyezése révén növeli a hitelminősítőkre való támaszkodást. Azt is hangsúlyozták, hogy a tervezett áttételi ráta és a tőkekövetelmény-minimum küszöbértékére (output floor) vonatkozó szabályozás célja is az, hogy a modellkockázatokat csökkentse, miközben a Bázeli Bizottság egyáltalán nem vizsgálta meg azt, hogy ezeknek a fékeknek milyen kölcsönhatásaik vannak. Az IRB használatára vonatkozó korlátozások helyett a bankok képviselői amellett tették le a voksukat, hogy inkább a modellekere és implementációjukra vonatkozó szabályozói előírásokat kellene tovább egységesíteni. A Bázel-III. végső verziójában az IRB-használat korlátozására vonatkozó elöírások is nagymértékben elmozdultak a bankok érdekei felé: az IRB használatának kivezetése a pénzügyi intézmények és a nagyvállalatok esetében lekerült a napirendröl, csak a fejlett IRB használatát tiltották meg a bankok és egyéb pénzügyi intézmények, valamint egy harmadik módon definiált nagyvállalati szegmens esetében. ${ }^{17}$ Az IRB használatát kizárólag az értékpapírosítási pozíciók esetében tiltotta meg az új szabályozás.

Van még egy olyan szabályozási eszköz, amely potenciálisan alkalmas lehetett volna arra, hogy a globális pénzügyi válság után alacsonynak bizonyuló banki tőkekövetelményeket megnövelje, úgy, hogy közben a szabályozás kockázatalapú jellege nem változik. Ez az IRB-modellekbe beépített 1,06-os szorzó (skálázó tényezö) növelése lehetett volna. A modell eredményeihez kötődő szorzó nagyon hasonló hatásmechanizmusú eszköz, mint a tőkekövetelmény-minimum küszöbértékét meghatározó szabályozás, hiszen mindkettő a modellszámítás eredményeként kapott tőkekövetelményt növeli. Van azonban a kettő között egy lényeges különbség: a skálázó tényező esetében a tőkekövetelmény számításának kizárólagos alapja továbbra is a modell által adott eredmény, így egyáltalán nem változtat a tőkekövetelmény kockázatalapúságán,

\footnotetext{
${ }^{13}$ Ez ugyanaz a konzultációs dokumentum, amelyben az inputküszöbértékekre vonatkozó javaslat is szerepel.

${ }^{14}$ Azok a vállalatok, amelyek olyan vállalatcsoporthoz tartoznak, ahol a csoport konszolidált éves árbevétele meghaladja az 50 milliárd eurót.

${ }^{15}$ Azok a vállalatok, amelyek olyan vállalatcsoporthoz tartoznak, ahol a csoport konszolidált éves árbevétele 200 millió és 50 milliárd euró között van.

${ }^{16}$ A konzultációs időszak alatt a Bázeli Bizottságnak küldött vélemények megtalálhatók: https:// www.bis.org/bcbs/publ/comments/d362/overview.htm.

${ }^{17}$ Azok a vállalatok, amelyek olyan vállalatcsoporthoz tartoznak, ahol a csoport konszolidált éves árbevétele meghaladja az 500 millió eurót.
} 
és emiatt az abban foglalt ösztönzési struktúrán sem. Ennek jó oldala, hogy nem fogja vissza a kockázatmérés és kockázatkezelés fejlesztésére irányuló ösztönzést, míg rossz oldala, hogy nem csökkenti a jelenlegi rendszer rossz ösztönzőit.

A Bázel-III. végső változata azonban nem megnövelte, hanem eltörölte az IRBfüggvénybe eredetileg beépített skálázó tényezőt, arra hivatkozva, hogy a tőkekövetelmény-minimum küszöbértékét már nem a Bázel-I. módszerrel, hanem az új standard módszerrel számított tőkekövetelményhez köti. A történethez még az is hozzátartozik, hogy miközben a tőkekövetelmény-minimum küszöbértékéről nagy nyilvánosság előtt folyt a vita, a skálázó tényező eltörlésének kérdését egyáltalán nem vitatták meg széles körben és a nyilvánosság elött, a végső dokumentumban egy lábjegyzet tartalmazza az indoklását (BCBS [2017a] 2. o.). Ez szintén a bankok erős lobbierejére utal, az IRB-módszert alkalmazó bankok szabályozói változások miatti, szándékolt tőkenövelését szinte „titokban” hat százalék erejéig ellensúlyozza a szabályozás a skálázó tényező utolsó pillanatban való eltörlésével.

\section{Következtetések}

A bankszabályozás fejlődése jól kivehető irányokat követ, a válság előtt a kockázatalapú bankszabályozás elöretörése, míg a válságot követően annak visszaszorulása figyelhető meg. A kockázatalapú szabályozás nem kockázatérzékeny elemekkel történő kiegészítésének az a célja, hogy csökkentse a kockázatalapú szabályozásnak azokat a hiányosságait, amelyek a globális pénzügyi válság idején nyilvánvalóvá váltak.

A tanulmány a hitelkockázati tőkekövetelmény változásainak szempontjából elemezi a két irányváltást. A hitelkockázati modellezésen alapuló IRB-módszert elemezve különbséget tesz a modellkockázatok két típusa: a modellek megfelelőségének kockázata és a modellek pontosságának és egységes implementálásának kockázata között. Ez a megkülönböztetés fontos, hiszen ennek segítségével lehet rámutatni arra, hogy a modellkockázatoknak van egy olyan szegmense, amely jobb modellezési gyakorlattal sem csökkenthető. Ezzel szemben a modellek pontosságának és egységes implementálásának kockázata jól mérsékelhető a pontosabb és részletesebb modellezési útmutatókkal és validációs módszerekkel. Az erre irányuló változásoknak is erős korlátját jelentik azonban az ösztönzési struktúrák, hiszen a bankok legfontosabb érdeke a kockázattal korrigált tőkemegtérülés (RAROC) növelése, függetlenül attól, hogy milyen szabályozási eszközök vannak érvényben.

Ennek tükrében az a szabályozási szemléleti fordulat, amely a válság előtt a kockázatalapú szabályozás elöretörését eredményezte, „egy lépés elöre, egy lépés hátra” típusú fordulatnak tekinthető. Képes volt arra, hogy számottevően csökkentse a szabályozás kockázatérzékenységének hiányából fakadó pénzügyi stabilitási problémákat, de egyben új, nem kevésbé súlyos problémákat teremtett. Eközben a banki kockázatkezelés látványos fejlődése azt az illúziót keltette, hogy a bankok szabályozási tőkekövetelménye egyre erösebben arányos a bankok által vállalt kockázatokkal, és ezért megfelelő eszköz a betétesek pénzének védelmére. Az IRB-modellek kifejlesztése valóban hozzájárult ahhoz, hogy a bankok jobban kezeljék a kockázataikat 
a válságtól mentes időszakokban. Azonban, a Goodhart-törvénnyel összhangban, amint a modellalapú szabályozás (kockázatmérés) szabályozói standarddá vált, meg is szünt megfelelő mérési módszer lenni.

A válság után a Bázel-III. szabályozás keretében bevezetett, nem kockázatérzékeny szabályozási eszközök, a tőkeáttételiráta-előírás, az IRB-modell bank által meghatározható paramétereire és az IRB-modellel számolt tőkekövetelmény szintjére vonatkozó kötelező minimum-küszöbértékek elöírása, valamint az IRB-módszer egyes részportfóliók használatára vonatkozó korlátozása kapcsán elemeztük azok hatásosságát, továbbá, hogy miként befolyásolták az ösztönzési struktúrákat.

Azt találtuk, hogy a tőkeáttételi ráta szabályozása potenciálisan jó kiegészítő eszköz a kockázati súlyozás negatív ösztönzőinek ellensúlyozására és a szabályozási tőkekövetelmény emelésére, azonban az előírt szintje annyira alacsony, hogy nem valószínü, hogy a gyakorlatban képes lesz ezen célok szolgálatára. Hasonlóképpen: az IRBmodellel számított tőkekövetelmény felhasználását korlátozó minimum-küszöbérték csökkenti a kockázati súlyok manipulálásának terepét, ugyanakkor a kockázatkezelés fejlődése ellen is hathat. 72,5 százalékos szintje viszont elég alacsonynak tekinthető ahhoz, hogy megmaradjon a bankok modellfejlesztési érdekeltsége, de kérdéses, hogy elég magas-e ahhoz, hogy a modellmanipulációk ellen hatásos legyen. Az IRB-használatra vonatkozó korlátozások pedig oly mértékủ kompromisszumokkal terheltek, hogy aligha lesz komoly hatásuk akár a szabályozás hatásosságára, akár pedig mögöttes ösztönzési struktúrákra.

A cikk legföbb következtetése, hogy a kevert, kockázatalapú és nem kockázatérzékeny szabályozóeszközöket tartalmazó szabályozás alapvetően jobb, mint a teljesen kockázatalapú vagy az egyáltalán nem kockázatérzékeny szabályozás. A kevert rendszerek elősegíthetik, hogy sem a kockázatalapú, sem pedig a nem kockázatérzékeny szabályozás rossz ösztönzési rendszere ne tudjon teljesen érvényesülni, hiszen jóval nehezebbé teszi a szabályozási arbitrázs kivitelezését a két rendszer eltérő ösztönzési struktúrája miatt. A jelenlegi bankszabályozási rendszer azonban olyan bonyolulttá és nehezen követhetővé vált, ${ }^{18}$ hogy a mögöttes ösztönzési struktúrák is csak menet közben fognak kikristályosodni, ami számos nem várt mellékhatást eredményezhet a jövőben. A tanulmány arra is rámutatott, hogy a kockázatalapú és a nem kockázatérzékeny szabályozás közötti vagy ennek valamilyen keverékére irányuló döntést hibás pusztán kockázatkezelési technikai problémaként kezelni, mert az legalább annyira politikai, mint modellezési kérdés.

\section{Hivatkozások}

Acharya, V.-Engle, R.-Pierret, D. [2014]: Testing macroprudential stress tests: The risk of regulatory risk weights. Journal of Monetary Economics, Vol. 65. 36-53. o. https://doi. org/10.1016/j.jmoneco.2014.04.014.

\footnotetext{
${ }^{18}$ A tőkeszabályozás számos elemével, így például a makroprudenciális kockázatok kezelésére bevezetett tőkepufferekkel vagy a helyreállítás-tervezés keretében megkövetelt, tőkévé konvertálható forrásokkal a cikkben még említés szintjén sem foglalkoztunk.
} 
Acharya, V.-Schnabl, Ph [2009]: How Banks Played the Leverage Game. Megjelent: Acharya,V.-Richardson, M. (szerk.): Restoring Financial Stability. How to Repair a Failed System. John Willey and Sons, Hoboken-New Yersey, 83-100. o. https://doi. org/10.1002/9781118258163.ch2.

Admati, A. [2016]: The missed opportunity and challenge of capital regulation. National Institute Economic Review, Vol. 235. No. 1. http://journals.sagepub.com/doi/10.1177/ 002795011623500110.

Admati, A.-Hellwig, M. [2013]: The Bankers' New Clothes. What's wrong with banking and what to do about it. Princeton University Press, Princeton, https://doi.org/10. $1515 / 9781400851195$.

Adrian, T.-Shin, H. S. [2010]: Liquidity and leverage. FRB of New York Staff Report, No. 328. http://dx.doi.org/10.2139/ssrn.1139857.

Ayuso, J.-PÉrez, D.-SAurina, J. [2004]: Are capital buffers pro-cyclical? Evidence from Spanish panel data. Journal of Financial Intermediation, Vol. 13. No. 2. 249-264. o. https:// doi.org/10.1016/s1042-9573(03)00044-5.

Avery, R. B.-Berger, A. N. [1991]: Risk-based capital and deposit insurance reform. Journal of Banking and Finance, Vol. 15. No. 4-5. 847-874. o. https://doi. org/10.1016/0378-4266(91)90103-S.

Barth, J. R.-Caprio, G., JR.-Levine, R. [2005]: Rethinking Bank Regulation. Till Angels Govern. Cambridge University Press, Cambridge, xv-xvi. o. https://doi.org/10.1017/ CBO9780511753817.002.

BARTh, J. R.-PrABhA, A. P.-Lu, W. [2013]: Do interest groups unduly influence bank regulation? CESifo DICE Report, Vol. 11. No. 4. 19-25. o. https://www.cesifo-group.de/DocDL/ CESifoDICEreport413.pdf.

BCBS [1996]: Amendment to the capital accord to incorporate market risk. Bázeli Bankfelügyeleti Bizottság, https://www.bis.org/publ/bcbs24.htm.

BCBS [1999a]: Capital requirements and bank behavior. The impact of the Basel Accord. Bázeli Bankfelügyeleti Bizottság, Working Paper, No. 1. https://www.bis.org/publ/bcbs_ wp1.htm.

BCBS [1999b]: Credit Risk modelling. Current practices and applications. Bázeli Bankfelügyeleti Bizottság, https://www.bis.org/publ/bcbs49.pdf.

BCBS [1999c]: A new capital adequacy framework. Consultative Paper, Bázeli Bankfelügyeleti Bizottság, https://www.bis.org/publ/bcbs50.pdf.

BCBS [2001]: The New Basel Capital Accord. An explanatory note. BIS, https://www.bis.org/ publ/bcbsca01.pdf.

BCBS [2004]: Basel II: International Convergence of Capital measurement and Capital Standards. A Revised Framework. BIS, https://www.bis.org/publ/bcbs107.pdf.

BCBS [2005]: An Explanatory Note on Basel II IRB Risk Weight Functions. BIS, https://www. bis.org/bcbs/irbriskweight.pdf.

BCBS [2009]: Enhancements to Basel II framework. BIS, https://www.bis.org/publ/bcbs157.pdf. BCBS [2014a]: Basel III leverage ratio framework and disclosure requirements. BIS, https:// www.bis.org/publ/bcbs270.pdf.

BCBS [2014b]: Capital floors: The design of a framework based on standardized approaches. Consultative Document. BIS, https://www.bis.org/bcbs/publ/d306.pdf.

BCBS [2016a]: Regulatory consistency assessment programme (RCAP) - Analysis of riskweighted assets for credit risk in the banking book. BIS, https://www.bis.org/bcbs/publ/ d363.pdf. 
BCBS [2016b]: Reducing variation in credit risk-weighted assets: Constraints on the use of internal model approaches. BIS, https://www.bis.org/bcbs/publ/d362.htm.

BCBS [2017a]: Basel III: Finalizing post-crisis reforms. BIS, https://www.bis.org/bcbs/publ/ d424.pdf.

BCBS [2017b]: Finalizing Basel III - In brief. BIS, https://www.bis.org/bcbs/publ/d424_ inbrief.pdf.

Behn, M.-Haselmann, R.-VIG, V. [2016]: The limits of model-based regulation. SAFE Working Paper Series, No. 75. 1928 https://doi.org/10.2139/ssrn.2523383.

CAlomiris, CH. [2017]: Reforming Financial Regulation after Dodd-Frank. Manhattan Institute for Policy Research, Kindle edition.

Catarineu-Rabell, E.-Jackson, P.-Tsomocos, D. P. [2003]: Procyclicality and the new Basel Accord: Banks' choise of loan rating system. Bank of England Working Paper, No. 181. https://doi.org/10.2139/ssrn.425782.

Cook, P. [1990]: International Convergence of Capital Adequacy Measurement and Standards. Megjelent: Gardner, E. (szerk.): The Future of Financial Systems and Services. Macmillian, 310-335. o. https://doi.org/10.1007/978-1-349-10439-0.

CoOper, K.-Kolari, J.-Wagster, J. [1991]: A note on the stock market effects of the adoption of risk-based capital requirements on international banks in different countries. Journal of Banking and Finance, Vol. 15. No. 2. 367-381. o. https://doi.org/10.1016/0378-4266(91)90073-U.

Cordell, L. R.-KING, K. K. [1995]: A market evaluation of the risk-based capital standards for the U.S. financial system. Journal of Banking and Finance, Vol. 19. No. 3-4. 531-562. o. https://doi.org/10.1016/0378-4266(94)00138-s.

Danielsson, J. [2008]: Blame the Models. Journal of Financial Stability, Vol. 4. No. 4. 321328. o. https://doi.org/10.1016/j.jfs.2008.09.003.

Danielsson, J.-Shin, H. S. [2003]: Endogenous Risk. Megjelent: Modern Risk Management. A history. Risk Books, London, 297-313. o.

Danielsson, J.-Embrechts, P.-Goodhart, C.-Keating, C.-Muennich, F.-Renault, O.Shin, H. S. [2001]: An Academic Response to Basel II. FMG Special Paper, No. 130. https:// www.bis.org/bcbs/ca/fmg.pdf.

Diamond, D.-RAJAN, R. [2000]: A theory of bank capital. Journal of Finance, Vol. 55. No. 6. 2431-2465. o. https://doi.org/10.1111/0022-1082.00296.

EBA [2015]: Future of the IRB Approach. Discussion Paper. Európai Bankhatóság, London, EBA/DP/2015/01, https://www.eba.europa.eu/documents/10180/1003460/EBA-DP2015-01+DP+on+the+future+of+IRB+approach.pdf.

EBA [2016]: The EBA's regulatory review of the IRB approach. Conclusions from the consultation on the Discussion Paper on the future of IRB approach. Európai Bankhatóság, London, https://www.eba.europa.eu/documents/10180/1360107/EBA+Report+on+the+regulatory+ review+of+the+IRB+Approach.pdf.

EBA [2017a]: EBA Report on IRB modelling practices. Európai Bankhatóság, London, november, https://www.eba.europa.eu/documents/10180/1720738/EBA+Report+on+IRB+modell ing+practices.pdf/0212ecde-426d-4e18-84f8-04b036dcce00.

EBA [2017b]: Results from the 2017 low default portfolios (LDP) exercise. EBA Report. November 14. https://www.eba.europa.eu/documents/10180/15947/EBA+Report+results+ from+the+2017+LDP+Credit+Risk+benchmarking.pdf.

Eyssell, T.-Arshadi, N. [1989]: The wealth effects of the risk-based capital requirement in banking. The evidence from the capital market. Journal of Banking and Finance, Vol. 14. No. 1. 179-197. o. https://doi.org/10.1016/0378-4266(90)90043-2. 
FSB [2017]: 2017 list of global systematically important banks (G-SIBs). Pénzügyi Stabilitási Tanács, http://www.fsb.org/2017/11/2017-list-of-global-systemically-important-banks-g-sibs. Gambacorta, L.-Mistrulli, P. E. [2003]: Bank capital and lending behavior: Empirical evidence for Italy. Banca d'Italia Termi di discussione (Economic Working Papers), No. 486. Goodhart, C.-Hofmann, B.-Segoviano, M. [2004]: Bank Regulation and Macroeconomic Fluctuations. Oxford Review of Economic Policy, Vol. 20. No. 4. 591-615. o. https://doi. org/10.1093/oxrep/grh034.

Gordy, M. B. [2000]: A Comparative Anatomy of Credit Risk Models. Journal of Banking and Finance, Vol. 24. No. 1-2. 119-149. o. https://doi.org/10.1016/S0378-4266(99)00054-0.

Greenspan, A. [2008]: We will never have a perfect model of risk. Financial Times, március 17. Griffith-Jones, S.-Spratt, S. [2003]: The Pro-Cyclical Effect of the New Basel Accord. Institute of Development Studies, University of Sussex, Brighton.

Haselmann, R.-Wahrenburg, M. [2016]: Banks' internal rating models - time for a change? The "system of floors" as proposed by the Basel Committee. Európai Parlament, november, http://www.europarl.europa.eu/RegData/etudes/IDAN/2016/587364/IPOL_ IDA(2016)587364_EN.pdf.

Hellwig, M. [2010]: Capital Regulation after the Crisis: Business as Usual? Preprints of the Max Planck Institute for Research on Collective Goods, Bonn, No. 31. https://doi. org/10.2139/ssrn.1645224.

HuizingA, H. [2016]: Banks' internal rating models - time for a change? The "system of floors" as proposed by the Basel Committee. Európai Parlament, november, http:// www.europarl.europa.eu/RegData/etudes/IDAN/2016/587365/IPOL_IDA(2016) 587365_EN.pdf.

Jones, D. S.-Mingo, J. [1998]: Industry Practices in Credit Risk Modeling and Internal Capital Allocations. Implications for a Models-Based Regulatory Capital Standard: Summary of Presentation. Economic Policy Review, Vol. 4. No. 3. https://doi.org/10.2139/ssrn.1028747.

KanE, E. J. [1995]: Difficulties of transferring risk-based capital requirements to developing countries. Pacific-Basin Finance Journal, Vol. 3. No. 2-3. 193-216. o. https://doi. org/10.1016/0927-538x(95)00010-i.

KIRÁly Júlia [2002]: Szabályok és bukások. Hitelintézeti Szemle, 1. évf. 2. sz. 3-13. o.

Király Júlia-Mérő Katalin [2004]: Basel Scepticism. From a Hungarian Perspective. Megjelent: Gup, B. E. (szerk.): The New Basel Capital Accord. Thomson, 337-369. o.

Levring, P. [2017]: Bankers in Scandinavia Say Basel Rules Hit Them Unduly Hard. Bloomberg, december 7. https:/www.bloomberg.com/news/articles/2017-12-07/sweden-says-itwon-t-mechanically-raise-standards-after-basel.

LiNDQUist, K.-G. [2004]: Banks' buffer capital. How important is risk. Journal of International Money and Finance, Vol. 23. No. 3. 493-513. o. https://doi.org/10.1016/j.jimonfin. 2004.01.006.

Mariathasan, M.-Merrouche, O. [2014]: The manipulation of Basel risk-weights. Journal of Financial Intermediation, Vol. 23. No. 3. 300-321. o. https://doi.org/10.1016/j. jfi.2014.04.004.

Matherat, S. [2016]: Basel IV could bring us almost back to the start. Deutsche Bank, szeptember 12. https:/www.db.com/newsroom_news/2016/ghp/sylvie-matherat-basel-ivcould-bring-us-almost-back-to-the-start-en-11678.htm.

Mijs, W.-Sabatini, G. [2016]: EBF letter to the Basel Committee: Finalisation of Basel III without Output Floors. Európai Bankföderáció, Brüsszel, december 16. https://www.ebf. eu/wp-content/uploads/2017/01/Letter-to-BCBS-December-20161.pdf. 
Plosser, M.-Santos, J. [2014]: Banks' Incentives and the Quality of Internal Risk Models. Federal Reserve Bank of New York, Staff Reports, No. 704.

Resti, A. [2016]: Banks' internal rating models - time for a change? The "system of floors" as proposed by the Basel Committee, Európai Parlament, november, http://www.europarl. europa.eu/RegData/etudes/IDAN/2016/587366/IPOL_IDA(2016)587366_EN.pdf.

Segoviano, M. A.-Lowe, P. [2002]: Internal ratings, the business cycle and capital requirements: Some evidence from an emerging market economy. BIS Working Papers, No. 117. https://www.bis.org/publ/work117.htm.

Sheldon, G. [1996]: Capital Adequacy Rules and the Risk-Seeking Behavior of Banks. A Firm-Level Analysis. Swiss Journal of Economics and Statistics (SJES), Swiss Society of Economics and Statistics (SSES), Vol. 132. No. IV. 709-734. o.

TARullo, D. K. [2008]: Banking on Basel. The future of international financial regulation. Peterson Institute for International Economics, Washington, DC.

VAn Nieuw Kerk, B.-DE VRIEs, B. [2015]: Capital requirements for banks: What is the optimal combination of regulation, supervision and market discipline? Rabobank, október 21. https:// www.rabobank.com/en/images/article-capital-requirements-rabobank.pdf.

Verhoeven, S. [2016]: Why Dutch banks fear Basel's new capital floor. Zanders, március 1. https://zanders.eu/en/latest-insights/why-dutch-banks-fear-basels-new-capital-floor. 